\title{
Three Poems by Ma Hui and English Translations ${ }^{1}$
}

\author{
Leilei Chen \\ University of Alberta \\ Julie Robinson \\ University of Alberta
}

The English rendition of Ma Hui's poetry - a joint effort between me and Julie Robinson, an Edmonton-based poet-plays with the creative nature of literary translation on another level. Ma's poems attempt to capture the spirit of the $6^{\text {th }}$ Dalai Lama (1700s) through a creative translation infused with his own interpretation of Buddhism, history and humanity in a contemporary Chinese context. Our translation of Ma's version of Tsangyang Gyatso intends to keep alive the artistic soul of the Chinese original, but makes the English text speak sensibly to native speakers. This is why we use a different spacing mechanism for "When I was Calling Your Name" and "Heroes in the Floating Dust." We believe the poetic pauses in the stanza divisions offer the needed time for readers to linger in the surreal space the poems create, to process their kaleidoscopic images along the way, and to savour the familiar and unfamiliar flavours during this journey. In this case, we dance closely with the Chinese poet's creative endeavour.

\footnotetext{
${ }^{1}$ These three poems were read on October 1, 2019, by Julie Robinson at the Town \& Gown event on the occasion of the $10^{\text {th }}$ St. Jerome Translation Conference, at the University of Alberta, Edmonton.
} 


\section{When I Was Calling Your Name}

First we misunderstood each other standing apart on opposite sides of the Lhasa River

Then we understood each other reading the details

Going through so many sexless faces

I came to the mountains to repose practice

A seed dropped unnoticeably into the earth suddenly shook the plateau

Then lovers offered the most sensitive place for my heart to ache

The rain came

Many people waited to betray me with umbrellas

And as I called your name thunder cracked over my head 


\section{Heroes in the Floating Dust}

The weather changed faster than my mood

Catastrophe dawned more suddenly than fame

My heart turned cold

making all stumble at a curse

I started with the crime of which I was wrongly accused acting innocent

conspiring sophistication

My prospects ruined again and again by murderous prophecies

Only the scriptures carved in the bones

saved me from worldly affairs

I looked ahead

The heroes in the floating dust one by one failed and fell The beauties in the mirror little by little withered

Only for the purpose of death did I strive to live while others everywhere felt ashamed 


\section{Who Could See through Whom}

Drinking wine with rumours after dusk you hid yourself to your left face unclear What you were saying was like the withering leaf -when that leaf was falling toward the root and suddenly

the wind rose

One beautiful woman one drop of tear After love and lust ambition reigned everywhere Heart was heavy like salt yet without permission you turned around Turning around you saw the flying blossoms saw me You were surprised a little and became salty

I was called Buddha everywhere but my left eyelid was throbbing with you People called you me everywhere but your right eyelid was throbbing with Buddha We boiled each other with our eyes representing the bubbles of dreams at this point who could see through whom who could not see through whom Instantly karma arrived Instantly karma left ...

The white clouds were floating Solve the main problem all other problems will be solved 


\section{在我呼唤你的同时, 头上响起了雷声}

\section{先是在拉萨河两岸遥相误解}

不久便在细节中彼此注释

穿过一张张丧失了性别的面孔

来到群山中安息、修行

一粒无意间丢入土中的种子

无意间便轰动了高原

这时, 恋人们腾出最敏感的地方

供我心痛

下雨了

很多人等着用雨伞㙜负我

而在我呼唤你的同时

头上响起了雷声 


\section{浮沉中的英雄个个落隗, 镜中的美女悄悄迟暮}

天气先于我的心情而变化

灾难比信誉

还突然

心一冷

所有的人都在一句咒语上打滑

我从莫须有的罪名起步

形色简单

心术复杂

前程被充满杀机的预言一误再误

唯有刻在骨头上的经文

为我推脱世事

一眼望去

浮沉中的英雄个个落魄

镜中的美女悄悄迟暮

我为了死 オ一次又一次地活了下来

而其他的人却随处差愧 


\section{谁能把谁看破, 谁不能把谁看破}

流言就酒，黄昏后

你把自己藏在自己的左边

眉目不清

你正在说的那句话

如同那片枯叶一

那片枯叶

正在向树根飘落的时候

突然

起风了

一个美人一滴泪

情色之余

遍地雄心

心重如盐

你却擅自回头

回头便是飞花

便是我

你愣了愣

一下子就咸了

到处都是被称为佛的我

我左眼皮上竟然跳着你

到处都是被称为我的你

你右眼皮上依旧跳着佛

互相用眼睛煮着对方

演绎梦幻泡影 此刻

谁能把谁看破

谁不能把谁看破

一刹那缘来

一刹那缘去

…...

白云飘飘

一了百了 